\title{
高繰り返しエキシマレーザにおける レーザ出力のガス流速依存性
}

\author{
正員柿崎弘司（東芝） \\ 正員高木茂行 (東芝) \\ 正貝佐藤 三郎 (果芝) \\ 正員 後 藤 達 美 (東芝)
}

Dependence of Excimer Laser Energy on Gas Flow Velocity in High Repetition Rate Operations Koji Kakizaki, Member, Noboru Okamoto, Non-Member, Shigeyuki Takagi, Member, Saburo Sato, Member, Tatumi Goto, Member (Toshiba Corp.)

To investigate the dependence of laser energy on a gas flow velocity in high repetition rate operations, the excimer laser energy was measured by varying the gas flow velocity up to a repetition rate of $3 \mathrm{kHz}$. The laser energy decreased at a clearance ratio of around 2 and 4 in our apparatus. When the upstream pin electrodes for preionization were removed, these decreases were not observed. This suggests that the preionization discharge products flow into the main discharge region at an onset of the following discharge and decrease the laser energy.

In order to show the influence of the preionization discharge products, we have defined the avoidance ratio $A R(=d * f / v, d$ : distance between pin electrodes and a center of main electrode, f: repetition rate, $v$ : gas $f(0 w$ velocity). If $A R$ becomes an integral number, the filamentation is occured in following main discharges, resulting in laser energy reductions.

キーワード:エキシマレーザ、レーザ出力、ガス流速、繰り返し数、予備電離

\section{1 、まえがき}

エキシマレーザは、短波長の紫外域で高効率、大出力発 振が得られるので、その実用化が大いに期待されている。 現在、実用されているレーザのうちY A GレーザやCO2レ 一ザは、光の熱作用を利用するものであるが、エキシマレ 一ザは光子エネルギーが高いため、光化学作用としての和 用が可能であり、新たな応用分野への展開が注目されてい る。しかしながら、エキシマレーザは現在の技術では連続 発振ができず、そのパルス繰り返し数も数百 $\mathrm{Hz}$ z程度と低 い。そこで、実用化に際し、生産性、制御性を高めるため に高繰り返し動作が必要になる。

1979 年に、Wangら (米) がレーザガスを高圧タンク から放電部に噴射して、動作時間は。１秒程度と短いが、

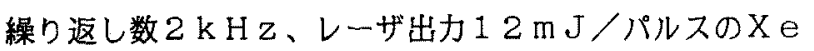
Fレーザを実現させた"゙。 X e C 1レーザに関しては、 1984 年にBaranov 5(露) が $1 \mathrm{k} \mathrm{H} \mathrm{z}$ までの発振を行つ
た(2)のに始まり、 $\mathrm{kHz}$ z越える高繰り返し発振に成功し た報告がこれまでに数件ある(3)．(4)。それとともに、 $\mathrm{kHz}$ 台の繰り返し領域では、レーザ発振の不安定化やレ 一ザ出力の低下の問題が報告されている。これらの原因は、 電極材料、予備電離強度、音響波・衝慗波などと放電安定 性との関係から論じられてきた(4)、(5)が、現在においても 飛躍的な性能向上が図られるまでには至ってはいない。 エキシマレーザの励起放電を安定に点郡するためには、 放電空間をあらかじか均一に弱電離状態にしておく必要が ある。この予備電離手段として、一般に主電極の両側にピ ン電極を配置し、スパーク放電によって発生する紫外線光 を用いる。

レーザ発振の繰り返し動作は、レーザガスを循環させ、 放電部のガスを次の放電までに置換することで可能となる。 このため、安定なレーザ発振を得るには綠り返し数に応じ て、置换に必要な速度以上のガス循環が必要となる(6)。本 論文では、高繰り返し動作においてレーザ出力がガス流速 
によって変化することから、ガス上流側の予備電離放電が 主放電に与える影響を検討した。また、その原因となる予 備電離用ピン電極の設置場所を変化させることにより、本 論文で提案したモデルの実証を行ったので報告する。

\section{2. 実跌装置}

実験に用いたX e C I エキシマレーザ装置 (7) の断面図を 図1に示す。発振波長は308 n mである。本装置の大き

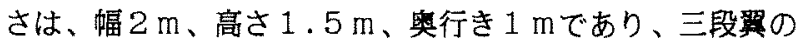
軸流ブロアを磁気カッブリングを介して外部モータにより 駆動することにより、放電部での最大ガス流速は、120 $\mathrm{m} / \mathrm{s}$ が得られる。ガス流は図中の矢印方向に流れ、放電 部に対して左側が上流、右側が下流となる。

図2に、放電部断面および励起回路の概略図を示す。励 起回路は容量移行型であり、主コンデンサCs $=15 \mathrm{nF}$ 、 ピーキングコンデンサC $\mathrm{P}=13 \mathrm{n} \mathrm{F}$ である。主電極は、幅 $40 \mathrm{~m} \mathrm{~m}$ のチャン型形状で、放電体積は、幅 $10 \mathrm{~m} \mathrm{~m}$ 、ギ ヤッブ長 $20 \mathrm{~mm}$ 、長さ280 m mである。UV自動予備 電離を行うピン電極は、銅にニッケルメッキを施したもの であり、主電極に沿って耐側に2 $0 \mathrm{~mm}$ 間隔で配置されて おり、ギャップ長は $2 \sim 3 \mathrm{~m} \mathrm{~m}$ である。主電極中心軸とピ ン電極の距離は $40 \mathrm{~m} \mathrm{~m}$ に設定してある。

実験に用いたレーザガスは、HCI $\mathrm{Xe}$ e = O. 4 / 3. $5 \mathrm{kPa} \mathrm{Ne}$ あるいはHeガスで希积しており、今 後それぞれ N e 希釈レーザガス、 $\mathrm{H}$ e 希秎レーザガスと呼 ぶことにする。ただし、 $\mathrm{Ne}$ 希釈の場合には、HC 1 希秎 用の Heが $8 \mathrm{kP}$ a混入されている。また、全ガス圧は 2 $79 \mathrm{kPa}$ としいる。

レーザ出力は、とくに断りの無い限り、装置を連続動作 させ、モレクトロン社製のエネルギーメータJ $50 \mathrm{HR}$ 用いて測定し、1パルス当たりのエネルギーとして与えた。 また、放電写真は、横方向の観測空からスチルカメラを用 いて、レーザ装置を数秒間動作させ 1 ○ショット程度を重 ね撮りした。

\section{3. 実駼桔果}

〈3・1〉ガス流速とレーザ出力の閏係 高繰り返し動作 においてガス流速が十分でないと、電極のガス下流側にア 一ク状の異常放電が発生し、レーザ出力は低下する。この 異常放電は、ガス流速を增加させることで抑止でき、さら に增加させても出力は変化しないと考えていた。しかし、 実際にガス流速を上げて出力測定してみたところ、罒 $3 に$ 示すように、ガス流速に対してレーザ出力が隼化すること がわかった。ここではN e 希粎レーザガスを使用し、主コ ンデンサの充電電圧 $V_{\mathrm{a}}$ は $21 \mathrm{kV}$ の場合であり、繰り返し 数をパラメータとして $3 \mathrm{k} \mathrm{H} \mathrm{z}$ までのレーザ出力を測定し た。

ガス流速に対するレーザ出力は、繰り返し数が高くなる とともに全体的に低下し、また、いずれの綝り返し数にお いても規則的な変化が見られる。そこで、この結果を次式

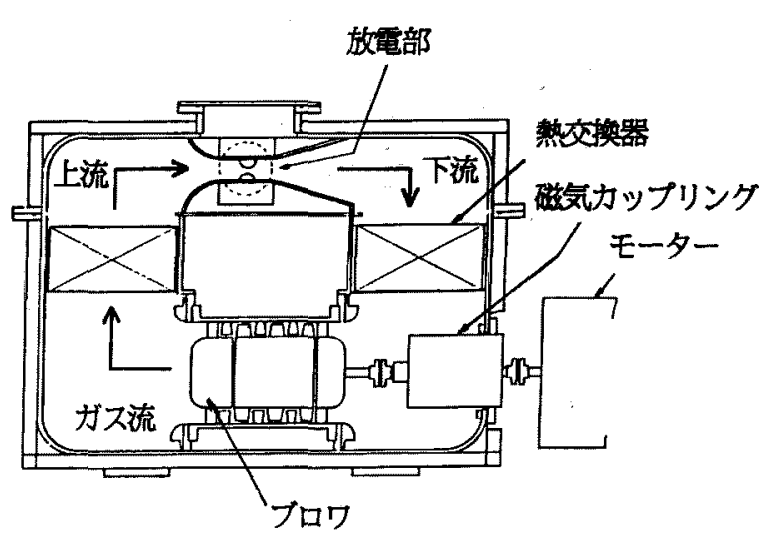

図1 エキシマレーザ断面図

Fig.1. Schematic cross section of the excimer laser.

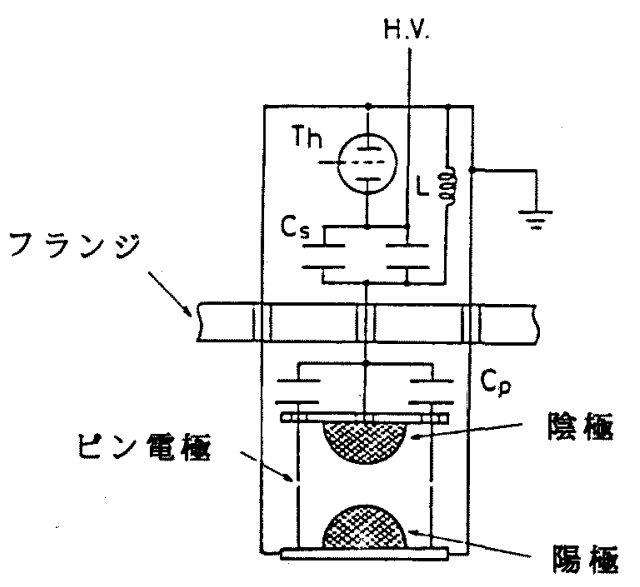

図2 放電部および放電回路

Fig.2. Discharge section and circuit.



図3 ガス流速に対するレーザ出力特性

Fig.3. Laser energy vs. gas flow velocity. 


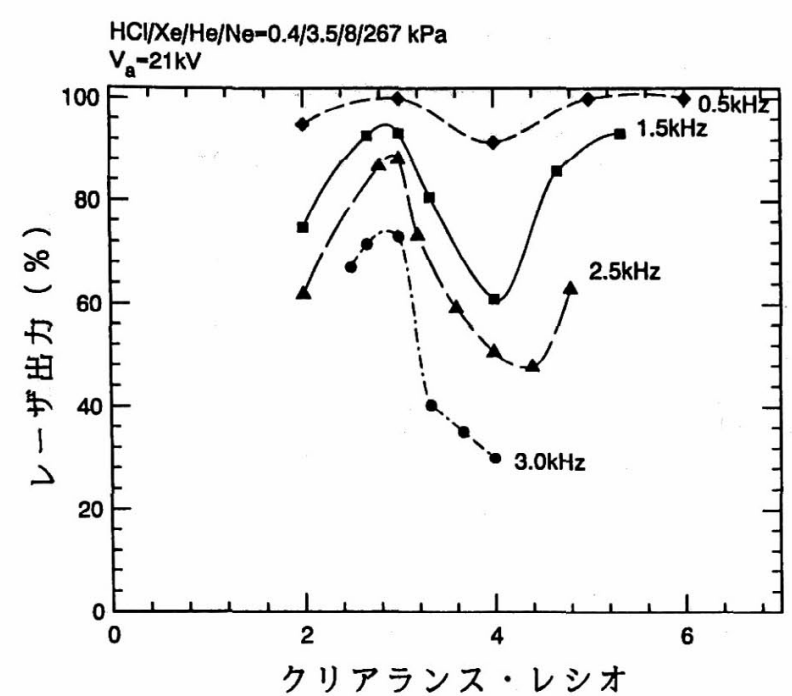

図4レーザ出力の C R 值依存性 （Nｅ希釈レーザガス）

Fig.4. CR-dependence of laser energy in Ne buffer laser gas.

で定義するC R 值（クリアランス・レシオ）によって整理 した。

$\mathrm{CR} \equiv \mathrm{v} /(\mathrm{w} * \mathrm{f})$

ここで、V：ガス流速（m/s)、w：ガス流方

向の放電幅 $(\mathrm{m}) 、 \mathrm{f}:$ 繰り返し数 $(\mathrm{Hz})$

C R 值はショット間のガスの入れ換わり回数を表し、ここ ではアーク状の異常放電発生の限界值 ${ }^{(6)}$ をえるものとは せず、ガス流速と繰り返し数の関係を示すものとした。

図4は、 $\mathrm{Ne}$ 希釈レーザガス、 $\mathrm{V}_{\mathrm{a}}=21 \mathrm{kV}$ におけるレ 一ザ出力のC R 值依存性を示す。綎軸に示す相対レーザ出 力は、繰り返し数 $1 \mathrm{H} \mathrm{z}$ 時の出力 $35 \mathrm{~m} \mathrm{~J} /$ パルスを 10 O \%としている。これより、各繰り返し数において、CR = 2、および 4 付近で出力が低下していることがわかる。 また、同じ C R 值に対しては、レーザ出力は繰り返し数の 増加とともに低下している。

同様に、 $\mathrm{H}$ e 希釈レーザガスで $\mathrm{V}_{\mathrm{a}}=24 \mathrm{kV}$ において得 られた結果を図 5 に示す。レーザ出力は、繰り返し数 2 $\mathrm{k} \mathrm{H} \mathrm{z}$ まで測定した。相対レーザ出力 $100 \%$ は $4 \mathrm{~m} \mathrm{~J}$ ノパルスに対応する。 $\mathrm{Ne}$ 希哷レーザガスの場合に比較し て、C R = 2 および 4 付近における出力低下分は大きいが、 C R 值に対する出力特性はほぼ同じような変化を示してい る。

なお、困4、図5において C R = 2 未満の測定值が示さ れてないのは、前述した異常放電が発生するためである。

〈3.2〉レーザ出力低下の原因 C R 值に依存してレー ザ出力が低下した原因を調べるため、CR值を変化させて 放電状態の観測を行った。図6は、 $\mathrm{Ne}$ 希釈レーザガス、 繰り返し数 $1 \mathrm{kH} \mathrm{z}$ そおいて、ガス上流側の観測空から撮 影した放電写真である。写真中、上側が陰極、下側が陽極

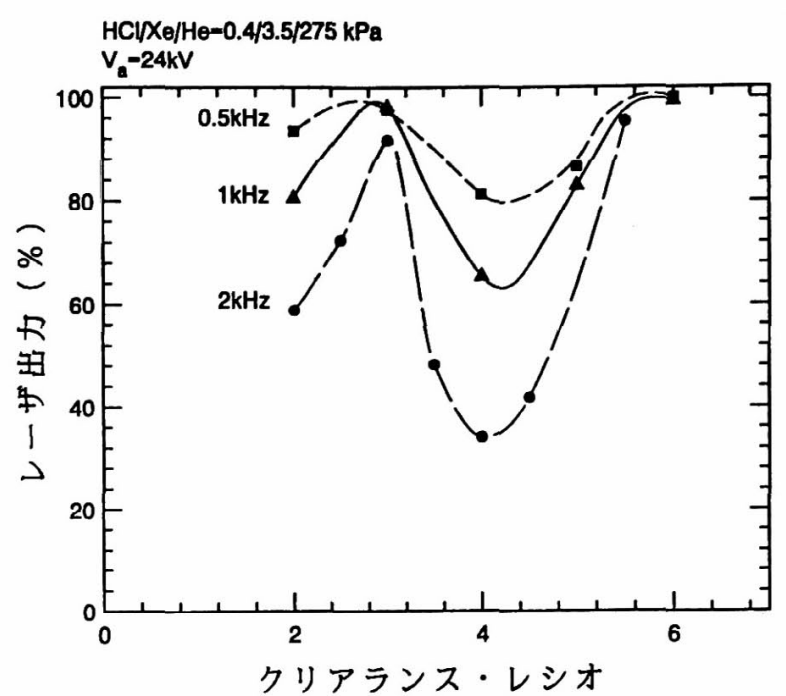

図 5 レーザ出力のC R值依存性 ( $\mathrm{He}$ 希釈レーザガス)

Fig.5. CR-dependence of laser energy in He buffer laser gas.

であり、その間の放電中の白点は予備電離放電発光、黒線 はガス上流の予備電離用ピン電極である。C R = 2 および 4 の場合には、このピン電極に対応して主放電中に電流の 集中が発生していることがわかる（写真中、白い線状の発 光）。それに対し、C R = 3 および 6 の場合にはピン電極 に対応した電流の集中がほとんど見られない。この結果か ら、レーザ出力の低下はガス上流側の予備電離放電に起因 すると考えられる。

そこで、図7に示すように、ガス上流側の予備電離放電 後のピン電極間のガス（以下、予備電離放電ガスと呼ぶ） が主放電に影響を与えると仮定して、次式のAR値（アボ イダンス・レシオ）を定義する。

$\mathrm{HCl} / \mathrm{Xe} / \mathrm{He} / \mathrm{Ne}=0.4 / 3.5 / 8 / 267 \mathrm{kPa}$ $V_{a}=21 k V \quad f=1 k H z$

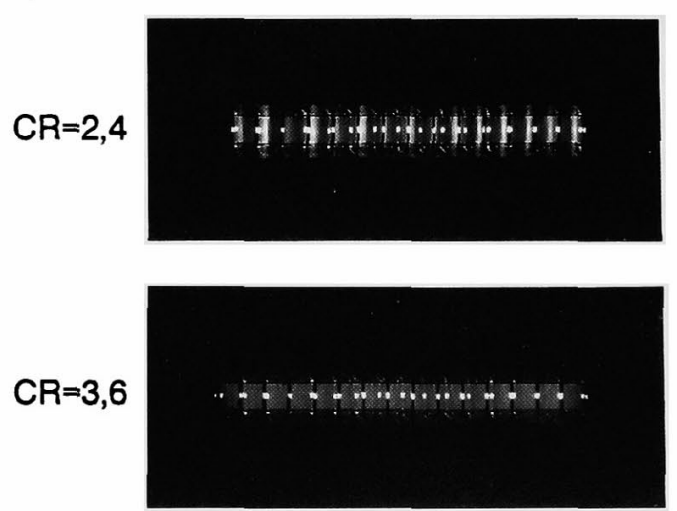

図6 C R 值変化に対する放電状態

Fig.6. Discharge conditions for CR. 


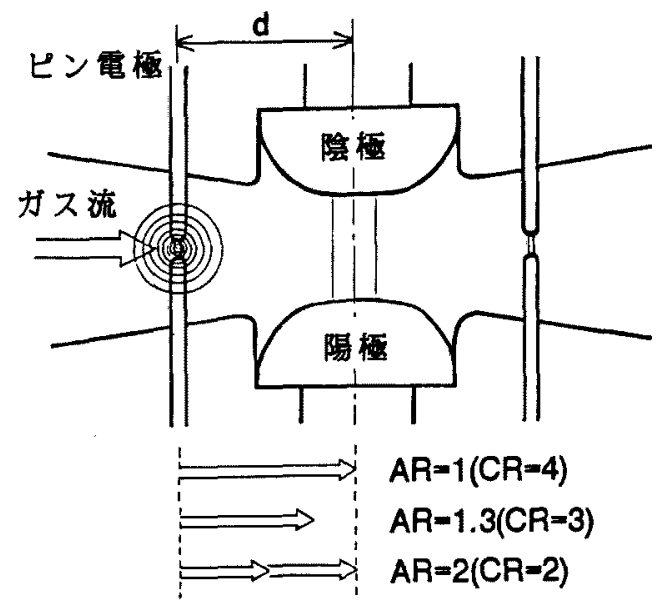

図7 レーザ出力のガス流速依存性のモデル図

Fig.7. Schematic model for dependence of laser energy on gas flow velocity.

$A R \equiv d * f / v$

ここで、 $\mathrm{d}$ ：主電極中心軸からガス上流側の予備

電離用ビン電極までの距離 $(\mathrm{m})$

$\mathrm{d} / \mathrm{v}$ は、予備電離放電ガスが主放電空間に到達するまで の時間を表し、繰り返し数fで決まる放電周期と同期する とき、AR值は整数となる。この值を用いて、レーザ出力 の低下原因を推察すると以下のようになる。A R=1のガ ス流速においては、予備電離放電ガスが、1ショット後の 放電点弧時に主放電空間へ流れ込み、また、AR=2のガ ス流速においては、予備電離放電ガスが2ショット後の放 電点弧時に主放電空間八流れ込む。その結果、主放電中に 電流の集中を発生させ、主放電を不安定化する。

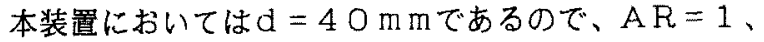
2 はそれぞれCR=4、2に対応した。AR値が整数にな らないときには、予備電離放電ガスは後続の放電点弧時に 主放電空間へ入り込まないので、レーザ出力を低下させな い。A $R=3$ 以上でも同様な現象は起こり得るが、本装置 においては、ガス流速不足により主放電が異常となり、レ 一ザ出力は得られない。

次に、 $A R=2$ の場合、すなわち、2ショット後のレー ザ出力への影響を確認するため、連続する3ショットのみ 放電を点弧するトリプル・パルス動作を試みた。図8は、 $\mathrm{H}$ e希釈レーザガスにおけるパルス間隔 $1 \mathrm{~m} \mathrm{~s}$ 、すなわち、

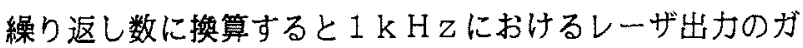
又流速依存性である。充電電圧は電源固有の特性により変 化するので、各パルスごとにこの值を眓中に示した。

ここで、第 1 ショットの出力はガス流速に依存せずほぼ 一定值を示している。これよりレーザ出力は、ガス流速を 増加した場合に発生するガス流の乱れや温度上昇などには 依存しないことがわかる。第 2 ショットの出力においては、 ガス流速 $20 \mathrm{~m} / \mathrm{s}(\mathrm{AR}=2$ に相当) 付近におけるレ一 ザ出力の低下は見られないが、ガス流速 $40 \mathrm{~m} / \mathrm{s}$ (AR

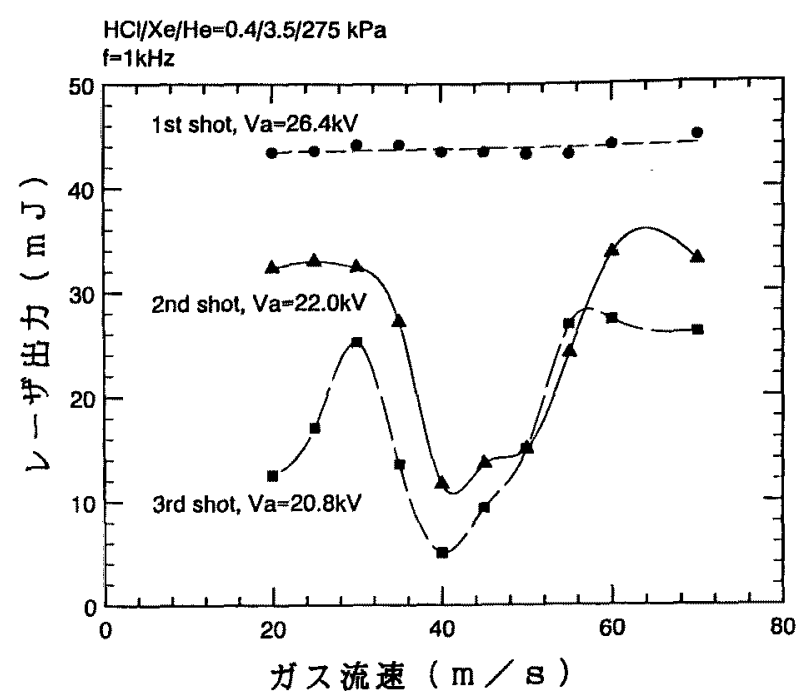

図8トリプル・パルス動作におけるレーザ 出力特性

Fig. 8. Laser energy vs. gas flow velocity in triple pulse operation.

=1に相当）付近におけるレーザ出力は低下していること がわかる。これより、AR=2付近における出力低下の原 因は、第 1 ショットの放電によるのではないことが明らか

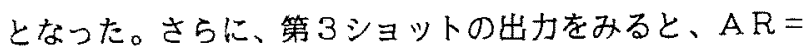
1、および2 付近で出力は低下しており、因50連続パル 又動作の場合とほぼ同じ変化を示している。これらの結果 は、 $\mathrm{AR}=2$ 付近の出力低下の原因が当該ショットから数 えて2ショット前の放電にあることを意味している。

〈3・3〉ガス上流侧ピン奄楆除去の効果ここように、 ガス上流側の予備電離放電ガスがレーザ出力低下の原因と 考えられるので、上流側のピン電極を取り除いた状態のも とで、レーザ出力のガス流速依存性を調べた。このとき、 ピーキングコンデンサの容量は変化させず、ピン電極数は 下流側のみで半数となった。罒9に、Ne希秎レーザガス、 $V_{\mathrm{a}}=21 \mathrm{kVkおける}$ 結果を示す。横軸は前節で定義した $\mathrm{AR}$ 值で整理しており、艇軸のレーザ出力 $100 \%$ は 1 $\mathrm{m} \mathrm{J} /$ パルスである。点線は、ガス上流側の予備電離ピン 電極を取り除く前、つまり、図3、図4 と同じ実験結果を 示し、害線は取り除いた後の結果を示している。これより、 上流側のピン電極を取り除いたことにより、各綝り返し数 に対し、レーザ出力はAR值に依存しなくなったことがわ かる。本結果は、ガス上流側の予備電離放電を点弧しない ことによるためであり、前節の推察を実証するものと考え られる。

しかしながら、繰り返し数の增加にともなうレーザ出力 の低下はまだ存在している。図9における繰り返し数の增 加による出力低下分は、図4におけるAR=1.3付近の 値とほぼ等しいため、この場合には上流側の予備電離放電 ガスが影篔していなかったといえる。したがって、この出 


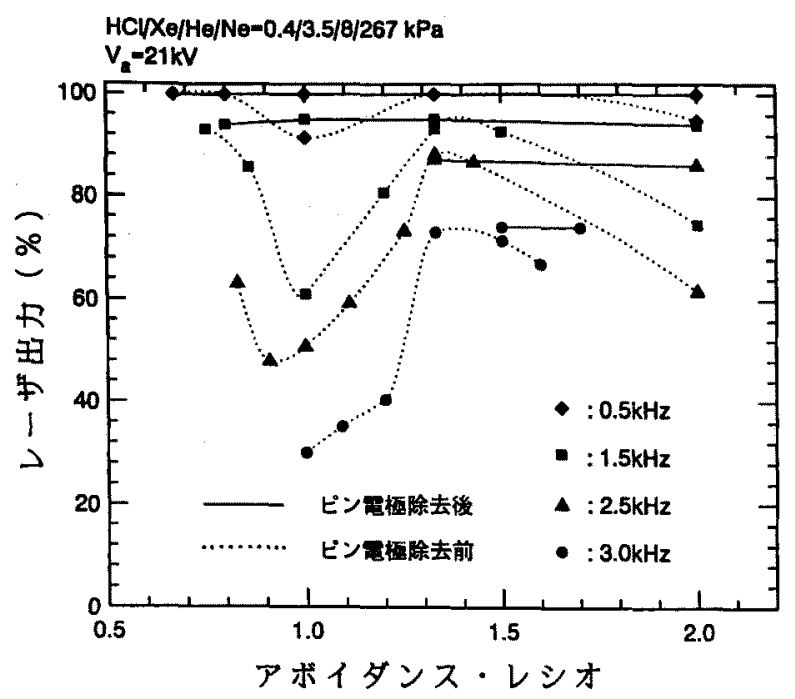

図9 ガス上流側ピン電極除去の効果

Fig.9. Effect of upstream pin electrodes removed.

力の低下については、別の原因を考えなければならない。 なお、綝り返し数 $2.5 \mathrm{k} \mathrm{H}$ zにおけるAR<1.3、同3 $\mathrm{kHz}$ ZにけるAR<1.5は、末測定のため図示されてい ない。

\section{4. 検 討}

これまでに述べた実験結果により、上流側の予備電離放 電ガスが、後続の放電点弧時に主放電空間に流入すると、 主放電中に電流の集中を発生させ、レーザ出力を低下させ ることが明らかとなった。また、その時のレーザ出打低 下分は、繰り返し数の增加にともない大きくなった。予備 電離放電ガスが電流の集中を発生させる機構として以下が 考えられる。

（1）予備電離放電直後のガスは、温度上昇によりガス密 度が希薄化しており、主放電空間に流れ込むと、そこでの 主放電の換算電界 $(\mathrm{E} / \mathrm{N})$ が局所的に高められ電離が促 進される。

（2）予備電離放電やその放電光によって生成される各種 粒子が主放電空間に流れ込み、局所的に電嚯を促進させる。

(1)については、予備電離放電に投入されたエネルギーの 大部分が熱になり、時間とともに拡散していくと考えられ る。したがって、綝り返し数が高くなり、パルス間隄が短 くなると、温度上昇に起因するガス密度摇らぎ $\Delta \mathrm{N} / \mathrm{N}$ は、 後続の放電点弧時までに消滅せずに残留する。放電に影響 を与えない $\Delta \mathrm{N} / \mathrm{N}$ の許容値としては、 $2 \%$ 程度が報告さ れている(8)。

（2）については、綝り返し数の增加とともに出力低下分が 大きくなっていることから、パルス間陾（1 ms以下）程 度の寿命を有する粒子の関与が考えられる。これらの粒子 の侯補としては、比較的寿命が長い算安定励起状態原子の

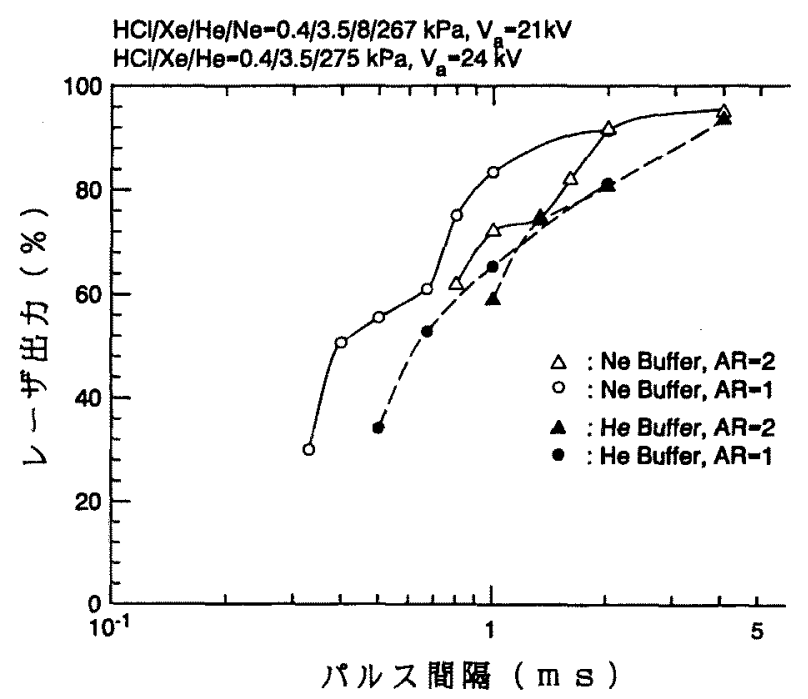

因10 パルス間陽時間とレーザ出力の関係

Fig.10. Relation between time interval and laser energy.

ほかに、実䮖により $\mathrm{m}$ sに及ぶ寿命が確認されている各種 イオンがあげられる(9)。

そこで、图 9 のAR=1および2におけるレ一ザ出力を、 パルス間隔（繰り返し数の逆数）の関数として書き換えた 結果を图 10 に示す。AR=2においては、2ショット後 の放電に影響を与えるのでパルス間隔を2 倍とした。図 1 ○は、時間が大きくなるとレーザ出力の低下割合が小さく なること、つまり、レーザ出力を低下させるガス密度摇ら ぎや放電生成物が時間とともに減少していくことを表して いる。 $\mathrm{He}$ 希釈レーザガスの場合のほうがパルス間隔に対 する出力の低下率は大きいが、希粉ガスに依らず $\mathrm{AR}=1$

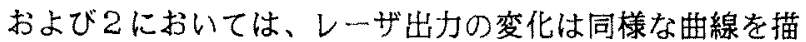
くことがわかる。また、出力の低下率は $1 \mathrm{~m} \mathrm{~s}$ 付近を境に 変化していることもわかる。

上流側の予備電離放電ガスに起因してレーザ出力が低下 するため、高繰り返し動作における安定動作領域は限定さ れる。これを実証するため、本実験においてはガス上流側 ピン電極の除去を行った。しかしながら、実際の装置にお いては、予備電離の強度や均一性(10)が非常に重要になる と考えられ、その十分な考虑が必要になる。本実験結果は、 A R 值により安定動作条件を決定することが可能となるの みならず、高繰り返しエキシマレーザ装置の放電部構造、 例えば予備電離ピン電極と主電極の位置関係や予備電離方 法等の設計に有益な指針を与える。

最後に、図9に示したように、ガス上流側のピン電極を 除去した後でも繰り返し数の增加にともない出力が低下し ている。この現象については、これまでに、綝り返し数の 增加にともなうピン電極間の破壊電圧の低下が観測されて おり(11)、これが一因となっていると考えられる。さらに、 前述した推䋈の(2)からは、粘性によりガス流速が○に近い 
主電極表面近傍においては、主放電により生成された各種 イオンや準安定励起状態原子が次の放電まで残留して、高 繰り返し動作を妨げることが示唆される。

\section{5.むすひ}

エキシマレーザにおいて繰り返し数とガス流速を変化さ せてレーザ出力を测定したところ、いずれの繰り返し数に おいても、ガス流速に対するレーザ出力は規則的な変化を 示した。この変化は、主電極に対してガス上流側の予備電 離用ピン電極を除去すると見られなくなったことから、予 備電離放電後のガスが原因となっていると考えられた。

そこで、上流側の予備電離放電ガスが、後続の主放電点 弧時に主放電空間に流れ込む条件を示すアボイダンス・レ シオ、AR值を定義した。AR値が整数に近づくとき、そ の数に等しいパルス数後の主放電中に、予備電離放電ガス に起因する電流の集中が発生し、レーザ出力が低下すると 考えられる。

終わりに、本研究を遂行するにあたり、有益なご助言い ただきました北海道大学工学部電気工学科酒井洋輔教授、 ならびに大阪大学レーザ核瀜合研究センタ一實野孝久講師 に深く感謝いたします。

本論文は、通商産業省工業技術院の産業科学技術研究開 発制度に基づき実施されている「超先端加エシステムの研 究開発」の一環として、新エネルギー・産業技術総合開発 機構から超先端加エシステム技術研究組合への委託事業に よりまとめたものである。

(平成 5 年 7 月 22 日受付)

\section{文献}

(1) C.P.Wang, and 0.L.Gibb :"2-kHz repetition rate XeF laser", IEEE J.Quantum Electron., 15, 318 (1979)

(2) V.Yu.Baranov, V.M.Borisov, Y.Yu.Vinokhodov, F.I. Vysikailo, and Yu.B.Kiryukhin :"Increase in the repetition frequency of $\mathrm{XeCl}$ laser pulses to $1 \mathrm{kHz}$, Sov.J.Quantum Electron., 14, 558(1984).

（3）高木茂行、杮崎弘司、岡本昇、佐藤三郎、後藤達美 : 「高繰り返しエキシマレーザーの開発 (X II ) - Xe 分圧低減による $4 \mathrm{kHz}, 200$ W動作一」、レーザ 一研究21、566(1993).

(4) M.L.Sentis, P.Delaporte, B.M.Forestier, and B.L. Fontaine :"Parametric studies of $\mathrm{x}$-ray preionized discharge XeCl laser at single shot and at high pulse rate frequency $(1 \mathrm{kHz})$ ", J. App I. Phys., 66, 1925(1989).

(5) R.V.Arutyunyan, V.M.Borisov, A.Yu.Vinokhodov, Yu.B.Kiryukhin, and A.N.Morozov :"Electrode effects in a pulse-periodic laser", Sov.J. Quantum Electron., 16, 1589(1986).
(6) G.S.Dzakowic and S.A. Wutzke :"High-pulse-rate glow-discharge stabilization by gas flow", J. Appl.Phys., 44, 5061(1973).

(7) S.Takagi, N.okamoto, K.Kakizaki, S.Sato and T. Goto :" $2.5 \mathrm{kHz}$ high repetition rate $\mathrm{XeCl}$ excimer laser", J.Appl.Phys., 68, 5927(1990).

（8）畑中秀和、河原暢朗、小原實、緑川克美、田代英夫： 「高繰り返し T E A C O 2 レーザーの放電領域のガス 流の乱れ」、レーザー科学研究、No.11、55(1989).

(9) M.R.Osborne :"Preionization electron density and ion decay measurements in an $x$-ray preionized rare-gas fluoride laser", J.Appl. Phys., 63, 32(1988).

(10) S.Takagi, S.Sato and T.Goto :"Electron density measurements in UV-preionized $\mathrm{XeCl}$ and $\mathrm{CO}_{2}$ laser gas mixtures", Jpn.J.Appl.Phys., 27, 2218 (1989).

(11) 柿崎弘司、岡本昇、高木茂行、佐藤三郎、後藤達美 : $「 5 \mathrm{kHz}$ 高繰返しエキシマレーザの基礎実験（XIV）」、 秋期応用物理学会学術講演会予稿集、11a-L-5、939 (1991).

柿崎 弘司（正員）昭和38年7月13日生まれ。昭和63年

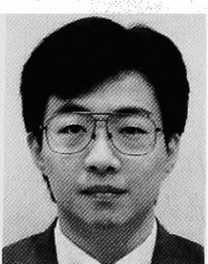
北海道大学大学院工学研究科修士課程修了。 同年4月（株）東芝入社。エキシマレーザの 研究開発に従事。現在、同社生産技術研究 所所属。

高木 茂行 （正員）昭和34年8月21日生まれ。昭和59年 名古屋大学大学院工学研究科修士課程修了。 同年4月（株）東芝入社。平成3年4月同大学 大学院工学研究科博士課程修了。工学博士。 エキシマレーザの研究開発に従事。現在、 同社生産技術研究所所属。

佐藤 三郎 (正員) 昭和 27 年5月26日生まれ。昭和56年

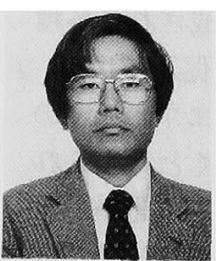
名古屋大学大学院工学研究科博士課程修了。 同年4月（株）東芝入社。工学博士。ガスレ 一ザの研究開発に従事。現在、同社生産技 術研究所所属。

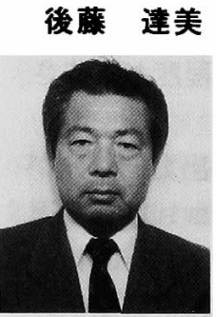

（正員）昭和 13 年5月23日生まれ。昭和 41 年 名古屋大学大学院工学研究科修士課程修了。 同年4月（株）東芝入社。ガスレーザの研究 開発に従事。現在、同社生産技術研究所所 属。 